ISSN 0258-7122

Bangladesh J. Agril. Res. 37(2): 235-250, June 2012

\title{
ASSESSMENT OF TECHNICAL EFFICIENCY OF INBRED HYV AND HYBRID RICE CULTIVATION AT FARM LEVEL
}

\author{
M. A. $\operatorname{SALAM}^{1}$, M. A. B. SidDiQUE ${ }^{1}$ AND J. PARVIN ${ }^{2}$
}

\begin{abstract}
This study is very important in the present perspective of rice economy as comparative economics of inbred HYVs and hybrid rice production was very scanty. As such, the present study was conducted to examine the relative productivity, profitability, and comparative technical efficiency of inbred HYVs and hybrid rice production in some selected areas of Gazipur district. The study was conducted in four villages in Sadar Upzila under Gazipur district, namely Kesurita, Martarchar, Harinal, and Samantapur. A total of 80 farmers from the four villages were interviewed consisting of 40 farmers for hybrid and 40 for inbred HYVs rice. Data were generated by personal interview using structured questionnaire through conducting farm level survey. The analysis revealed that there was no significant difference between farmers' practices and recommended rate of hybrid seed, TSP, and MP. But the farmers used urea and seed of inbred HYVs significantly higher than recommend rate. Hybrid farms incurred total cost of $\mathrm{Tk}$. 63377/ha and inbred farms incurred Tk. 61195/ha, respectively. Net returns obtained from hybrid rice was Tk. 59,056/ha whereas it was Tk. 42,818/ha for inbred HYVs rice. Average net return of inbred rice was 38\% lower compared to that of hybrid rice. Benefit cost ratio of inbred and hybrid production was estimated to be 1.93 and 1.70, respectively. The average yield of inbred HYV was $6.03 \mathrm{t} / \mathrm{ha}$ and by product was $4.50 \mathrm{t} / \mathrm{ha}$, while those of hybrid were $7.76 \mathrm{t} / \mathrm{ha}$ and $5.50 \mathrm{t} / \mathrm{ha}$, respectively. The estimates of technical inefficiency implied that education, farming experience, extension contact, land type, seedling age, and number of seedlings per hill were the major determinants of inefficiency for both inbred and hybrid rice growers. The mean technical efficiency was about $80 \%$ for inbred and $86 \%$ for hybrid rice producers, respectively, indicating hybrid rice growers were technically more efficient than inbred growers. Higher-level of education and more contact with extension agents were found to contribute in reducing technical inefficiency of both inbred and hybrid rice producers. Although, inbred and hybrid rice producers faced some problems, but it was more severe for hybrid.
\end{abstract}

Keywords: Hybrid, inbred, productivity, technical efficiency, rice.

\footnotetext{
${ }^{1}$ Scientific Officer and Principal Scientific Officer and Head, Agricultural Economics Division, Bangladesh Rice Research Institute (BRRI), Gazipur, ${ }^{2} \mathrm{MS}$ Student, Department of Agricultural Economics, Bangladesh Agricultural University (BAU), Mymensingh, Bangladesh.
} 


\section{Introduction}

Bangladesh is a densely populated developing country where a population of about 140 million is residing in the land area of 1, 47,570 sq km and about $71 \%$ of its population lives in rural areas (BBS, 2010). According to the World Bank report, total arable land in Bangladesh is about 61 percent of the total land area. Most of the farms are usually very small and marginal due to high population pressure. The total cultivated area was $8.03 \mathrm{~m}$ ha in 2003 but it reduced to 7.97 million hectares in 2005 (BBS, 2009) due to urbanization, industrialization and housing. The decreasing trend of arable land requires intensive use of land to produce more food for the extra million future generations. However, out of total cultivated areas, 2.75 million ha is single cropped, 3.92 million ha double cropped and 1.28 triple cropped (BBS, 2010).

The agriculture is the mainstay of the economy of Bangladesh. The economic development is inextricably linked with the performance of this sector. Agriculture provides nearly about $43.6 \%$ employments of its total labour forces (BSS, 2009). This sector contributes about $20.48 \%$ (BER, 2010) to the GDP of the economy as a whole of which crop sector share is about $12 \%$. Rice is the dominating crop sector of agricultural and the largest contributor to farm income of the majority of the farm population. Side by side, it is a vital source of non farm income related to trade and commerce of a large segment of the economy (Ahmed, 2001). Rice is the most strategic commodity in Bangladesh accounting for $70 \%$ calorie intake and about $35 \%$ of household expenditure. Out of 7.97 million ha cultivated area, about its $77 \%$ is devoted to rice (Jufiquar, 2009). Rice is being grown in the three seasons namely, Aus, Aman and Boro covering 1.07, 5.48 and 4.72 million ha of land respectively (BBS, 2009). On average $80 \%$ rice land was cultivated under HYVVs rice in the country and about $1 \%$ rice land is devoted to hybrid rice cultivation(DAE, 2010). Rice alone contributes about $95 \%$ to the total food grain production (BER, 2008). Although, the cropping intensity $(175.47 \%)$ of the country is the highest of the world, the decreasing land-man ratio more frequently reminds about the intensive use of land. So, there is the only way remains to face the increasing food requirement through adoption of modern MVs and hybrid rice which is relatively higher yielding cultivar. In some cases, MVs and local varieties must be replaced by hybrid rice to increase the level of rice production for ever growing populations. In Boro season, varieties like local variety, MVs and hybrid are being cultivated. Farmers' perceptions on growing hybrid and MVs are slightly different due to management practices. The study related to productivity, profitability and efficiency of both hybrid and inbred rice production is very scanty in Bangladesh. Therefore, the present study was undertaken at farm level with the following specific objectives:

a. to assess input use pattern, productivity and profitability of inbred and hybrid rice cultivations; 
b. to evaluate farmers' technical efficiency of inbred and hybrid rice production; and

c. to identify the socioeconomic constraints to rice cultivation.

\section{Methodology}

The study area "Gazipur district" was selected such that the technologies such as inbred HYV and hybrid rice were adopted there by the farmers as suggested by the local extension personnel. The farm level survey for the present study was conducted in Sadar Upzila under Gazipur district. Four villages namely Kesurita, Martarchar, Harinal and Samantapur were chosen purposively under the aforesaid Upazila on the basis of intensive rice cultivation and then farmers' list was colleted from Upazila extension office of Gazipur district. Then all farmers of each selected villages were categorized into two group such inbred HYVs and hybrid rice growers. Finally, 10 hybrid and 10 inbred HYVs growing farms from each village were selected using random sampling technique. However a total of 80 farmers from the four villages were interviewed consisting of 40 farmers for hybrid and 40 for inbred HYVs rice in this study. Data were generated by personal interview using structured questionnaire through conducting farm level survey. Both inbred and hybrid rice are generally transplanted in boro season from January to February and harvested from late April to the middle of May. Therefore, data were generated during the Boro season 2007-2008 (May to April, 2008). Both descriptive and inferential statistics were employed in analyzing the data and identifying the effects of key factors on rice production. The stochastic frontier model using Cobb-Douglas production function was used in measuring farm specific technical efficiency.

Technical efficiency of inbred and hybrid rice production was estimated with the parameters technique of production functions used by Bravo-Ureta and Evension, 1994 and Xiaosong $\mathrm{Xu}$ and Scott R. Feffrey, 1998 and cost decomposition procedure used by Kopp and Diewert, 1982 to estimate the technical efficiency.

The production function was specified as:

$\mathrm{Yi}=\mathrm{X}_{\mathrm{i}} \beta_{\mathrm{i}}+\varepsilon$

Where $\mathrm{Yi}=$ rice yield, $\mathrm{Xi}=$ is a $(\mathrm{Ki} \times 1)$ matrix of inputs, $\beta \mathrm{i}=$ is a $\left(\mathrm{K}_{\mathrm{i}} \times 1\right)$ matrix of parameters associated with $\mathrm{Xi}, \varepsilon \mathrm{i}=$ error terms, and $\mathrm{i}=$ the $\mathrm{i}^{\text {th }}$ observation.

The error term $\varepsilon_{\mathrm{i}}$ is made up of two independent components,

$\varepsilon_{\mathrm{i}}=\mathrm{v}_{\mathrm{i}}-\mathrm{u}_{\mathrm{i}}$

The error component $v_{i}$ represents the symmetrical disturbance that captures random errors/erroneous data. The error component $u_{i}$ is the asymmetrical term 
that captures the technical inefficiency of the observations and is assumed to be distributed independently of $\mathrm{v}_{\mathrm{i}}$.

Hence, the production frontiers may be as follows

$$
\begin{aligned}
& Y_{\mathrm{i}}=\mathrm{X}_{\mathrm{i}} \beta_{\mathrm{i}}+\left(\mathrm{v}_{\mathrm{i}}-\mathrm{u}_{\mathrm{i}}\right) \\
& \mathrm{Y}_{\mathrm{i}}=\mathrm{f}\left(\mathrm{X}_{\mathrm{i}} \beta_{\mathrm{i}}\right) \exp \left(\mathrm{V}_{\mathrm{i}}-\mathrm{U}_{\mathrm{i}}\right) .
\end{aligned}
$$

Where $\mathrm{v}_{\mathrm{i}} \sim \mathrm{N}\left(\mathrm{O}, \sigma_{\mathrm{v}}{ }^{2}\right)$ and $\mathrm{u}$ is truncated normal. The term $-\mathrm{u}$ is the one-sided error.

\subsection{Production frontier estimation with inefficiency equation}

The $\mathrm{U}_{\mathrm{i}} \mathrm{s}$ are non-negative random variables, associated with the technical inefficiency of production of the farmers in the population, assumed to be independently distributed such that the technical inefficiency effect for the ith farmer, $u_{i}$, is obtained by truncation (at zero) of the normal distribution with mean, $\mu_{\mathrm{I}}$ and variance, $\sigma^{2}$, such that

$$
\mathrm{U}_{\mathrm{i}}=\delta_{0}+\delta_{1} \mathrm{z}_{1 \mathrm{i}}+\ldots \ldots \ldots \ldots+\delta_{\mathrm{n}} \mathrm{Z}_{\mathrm{ni}} .
$$

Where $\mathrm{z}_{1 \mathrm{i}} \ldots \mathrm{z}_{\mathrm{ni}}$ are explanatory variables.

The maximum-likelihood estimates and inefficiency model, defined by equations (3) and (4) are simultaneously obtained by using the computer program FRONTIER Version 4.1 (Coelli 1996) which estimates the variance parameters in terms of parameterization

$\sigma_{\varepsilon}^{2}=\sigma_{\mathrm{v}}^{2}+\sigma_{\mathrm{u}}^{2}$

and

$\gamma=\sigma_{\mathrm{u}}{ }^{2} / \sigma_{\varepsilon}^{2}$

$\gamma$ is the ratio of variance of farm-specific technical efficiency to the total variance of output and has a value between zero and one.

The technical efficiency of a farmer at a given period of time is defined as the ratio of the observed output of the frontier output which could be produced by a full-efficient firm, in which the inefficiency effect is zero. Given the specifications of the stochastic frontier models ( 3 and 4 ), the technical efficiency of ith farmer, can be shown to be equal to

$$
\begin{aligned}
T E & =\exp (-U i) \\
& =Y_{i} / f\left(X_{i} \beta_{i}\right) \exp \left(V_{i}\right)=Y_{i} / Y_{i}^{*}
\end{aligned}
$$

Where, $Y_{i}{ }^{*}=f\left(X_{i} \beta\right) \exp \left(V_{i}\right)$ is the farm specific stochastic frontier. If $\mathrm{Y}_{\mathrm{i}}$ is equal to $\mathrm{Y}_{\mathrm{i}}^{*}$, them $T E_{i}=1$, reflects $100 \%$ efficiency. The difference between $Y_{i}$ and $Y_{i}^{*}$ is embedded in $\mathrm{u}_{\mathrm{i}}$ (Dey et al. 1999). If $U_{i}=0$, implying that production 
lies on the stochastic frontier, the farm obtains its maximum attainable output given its level of inputs. If $U_{i}<0$, production lies below the frontier which is an indication of inefficiency.

Thus, the technical efficiency of a farmer is between zero and one, inversely related to the inefficiency effect.

\subsection{Empirical model}

Cobb-Douglas and translog are two functions that dominate the technical efficiency in the literature. Since, the sample number is not very high, the translog specification could not be employed. The stochastic production function for the sample farmers is specified as:

$\operatorname{In} Y_{i}=\beta_{o}+\beta_{l} \ln \left(X_{1}\right)+\beta_{2} \ln \left(X_{2}\right)+\beta_{3} \ln \left(X_{3}\right)+\beta_{4} \ln \left(X_{4}\right)+\beta_{5} \ln \left(X_{5}\right)+\epsilon_{i}$

where, In = Natural logarithm;

$Y_{i}=$ Yield of paddy $(\mathrm{kg} / \mathrm{ha})$;

$\beta o=$ Constant

$\beta_{l}=$ Coefficient

$X_{I}=\operatorname{Seed}(\mathrm{kg} / \mathrm{ha})$

$X_{2}=$ Fertilizer $(\mathrm{kg} / \mathrm{ha})$

$X_{3}=$ Human labour (man-days/ha)

$X_{4}=$ Irrigation (no.)

$X_{5}=$ Insecticides (no.)

$\epsilon_{i}=$ Statistical noise/random disturbance term (in estimating technical inefficiency effects, This $\epsilon_{i}$ is further decomposed as $\mathrm{V}_{\mathrm{i}}-\mathrm{U}_{\mathrm{i}}$ where $V_{i}=$ random error and $U_{i}=$ non-negative random term associated with technical inefficiency.

The technical inefficiency effects, $U_{i}$ is defined as:

$U_{i}=\delta_{0}+\delta_{j} Z_{i}$

Where, $\delta_{j}=$ Unknown parameters to be estimated.

$Z_{1}=$ Farm size (ha)

$Z_{2}=$ Education (Years of schooling)

$Z_{3}=$ Age of ${ }^{\text {th }}$ farmer

$Z_{5}=$ Farming experience (years)

$Z_{4}=$ Land type dummy (value 1, if the land is low, 0 otherwise ) 


$$
\begin{aligned}
& Z_{6}=\text { No of contact with technology disseminators } \\
& Z_{7}=\text { Seedling age (days) } \\
& Z_{8}=\text { Seedlings (no/hill) }
\end{aligned}
$$

Frontier 4.1 packages (Coelli, 1996) was used to estimate the stochastic production function, which measures the inefficiency of the sample farms.

\section{Results and Discussion}

\subsection{Comparative input use pattern and productivity}

The use of seed in inbred rice cultivation was substantially higher $(61 \mathrm{~kg} / \mathrm{ha})$ than the recommended rate $(30 \mathrm{~kg} / \mathrm{ha})$. Most of the inbred rice growers used home supplied seed, whose germination rate was lower than quality seed. So, the farmers inclined to use more amounts of seeds than the recommendation. On the other hand, the use of seed rate for hybrid rice $(11.5 \mathrm{~kg} / \mathrm{ha})$ was slightly lower than the recommended rate because the germination capacity of hybrid seed is comparatively better. Sometimes the higher price of hybrid seed might have induced the farmers to reduce seed rate. Hybrid rice growers preferred single cropped and comparatively low land (clay loamy) for hybrid rice cultivation. The analysis reveals that inbred growers applied on an average 214 , 109 and $74 \mathrm{~kg} / \mathrm{ha}$ of Urea, TSP, and MP, respectively, while hybrid rice growers used at the rate of 181,86 and $49 \mathrm{~kg} /$ ha indicating that inbred rice growers used more amount of chemical fertilizers than hybrid rice growers. It might be due to more land fertility and there are more plant nutrients in low silted land soil. It is also important to mention that the majority of hybrid rice farmers used $\mathrm{ZnS04}$ $(2.98 \mathrm{~kg} / \mathrm{ha})$, but none of inbred growers used it. Hybrid growers used on an average 163 man-days/ha, while inbred rice growers used 156 man-days/ha. It indicated that human labour required for hybrid rice production was higher than that for inbred rice production as hybrid rice cultivation needs good management practices and more supervision. The operation wise distribution of human labour indicated that, the highest amount of human labour was employed for harvesting, carrying, threshing, storing and drying (58 man-days/ha for inbred and 67 mandays/ha for hybrid respectively) while weeding constituted the second highest proportion for inbred rice (39 man-days/ha) and for hybrid rice (45 man-days/ha), respectively. Frequency of irrigation application by both inbred and hybrid rice growers were 13-15 and 11-13 times, respectively. Both the growers applied herbicides only single time to their plots but hybrid rice growers applied pesticides of 1.5 time which was higher than inbred rice growers (1 time). The average yield of main and by product were $6027 \mathrm{~kg}$ and $4500 \mathrm{~kg}$ per ha for inbred, respectively while those were $7,757 \mathrm{~kg}$ and $5500 \mathrm{~kg}$ per ha, respectively, for 
hybrid rice farms. It indicated that the yield of hybrid rice is 33\% higher than that of inbred rice, while the by-product of hybrid is $37 \%$ than that of inbred rice.

Table1. Use of inputs for inbred and hybrid rice production.

\begin{tabular}{|c|c|c|c|}
\hline Items & Inbred & Hybrid & $\begin{array}{c}\text { Mean } \\
\text { difference } \\
\text { t-ratio }\end{array}$ \\
\hline Seed (kg/ha) & 61 & 11.5 & $49.5^{*}$ \\
\hline Fertilizer $(\mathrm{kg} / \mathrm{ha})$ : & 414 & 334 & $80 * *$ \\
\hline Urea & 214 & 181 & $33 * *$ \\
\hline TSP & 109 & 86 & $23^{\mathrm{ns}}$ \\
\hline MP & 74 & 49 & $25^{*}$ \\
\hline Gypsum & 17 & 16 & $1^{*}$ \\
\hline $\mathrm{ZnSo}_{4}$ & 0 & 2.98 & $-2.98 * *$ \\
\hline Insecticides (No.) & 1 & 1.5 & $-0.5^{\mathrm{ns}}$ \\
\hline Herbicides (No.) & 1 & 1 & $0^{\mathrm{ns}}$ \\
\hline Irrigation (No.) & $13-15$ & $11-13$ & $2^{*}$ \\
\hline Human labour (man-days/ha): & 156 & 163 & $7 * * *$ \\
\hline Family & 30 & 23 & $-7 * * *$ \\
\hline Hired & 126 & 140 & $14 * *$ \\
\hline Seedbed preparation & 8 & 9 & $1^{\mathrm{ns}}$ \\
\hline Weeding & 39 & 45 & $6^{\mathrm{ns}}$ \\
\hline $\begin{array}{l}\text { Seedling uprooting and } \\
\text { transplanting }\end{array}$ & 34 & 28 & $-6 * *$ \\
\hline Application of fertilizer & 3 & 3 & $0^{\mathrm{ns}}$ \\
\hline Application of Insecticide & 2 & 2 & $0^{\mathrm{ns}}$ \\
\hline Application of Irrigation & 12 & 14 & $2 * *$ \\
\hline $\begin{array}{l}\text { Harvesting, carrying ,threshing, } \\
\text { drying, winnowing and storing }\end{array}$ & 58 & 67 & $9 * * *$ \\
\hline \multicolumn{4}{|l|}{ Yield performance } \\
\hline Product & 6027 & 7757 & $17.30 * *$ \\
\hline By product & 4500 & 5500 & $10.00 * *$ \\
\hline
\end{tabular}

$* * *, * *$ and $*=$ Significant at $1 \%, 5 \%$ and $10 \%$ level, ${ }^{\text {ns }}$ Not significant, respectively. 


\subsection{Comparative cost structure of inbred and hybrid rice production}

Average human labour cost for hybrid rice farms was estimated to be Tk. 24,375/ha while average human labour cost of inbred farms was estimated to be Tk. 23,310/ha. The cost of power tiller for inbred farms was Tk. 4630/ha while the corresponding cost for hybrid rice farming was Tk. 4970/ha. The cost of inbred and hybrid seeds per hectare were Tk. 1525/ha and Tk. 3162.5/ha, respectively. Hence, it was evidence that seeds costs of hybrid rice cultivation were 2 times higher compared to that of inbred rice and it may be due to high price of hybrid rice seed. The chemical fertilizer cost of Inbred rice cultivation was a bit higher (Tk. 7400/ha) than that of hybrid rice (Tk.5905/ha) which is opposition with common notions. Hybrid rice growers used relatively a bit lower amount of chemical fertilizer compared to that of inbred rice farmers. This may be because of the hybrid rice was transplanted in relatively low land with high fertile soil in the study areas during the study period. It revealed that Inbred growers paid lesser amount of insecticides cost (Tk.895/ha) than that of hybrid rice growers (Tk.1375/ha). It is evident that cost of irrigation was same for both hybrid and inbred HYVs (Tk.9500/ha). Inbred rice growers spent Tk185/ha for herbicides application but hybrid rice farmers spent Tk 303/ha for this item. Average land use cost for both hybrid and inbred inbred HYV was same (Tk. 12959/ha). It is important to note that land use cost in Gazipur is increasing day by day. It might be observed that interest on operating capital was calculated by taking into account all variable costs of inbred and hybrid rice production. An average interest on operating capital was estimated at Tk.791/ha for Inbred farms and Tk. 827/ha for Hybrid farms, respectively. Hybrid farms incurred total cost of Tk.63377/ha and inbred farms incurred Tk. 61195/ha, respectively. It seemed that per hectare total cost of hybrid rice production was about $4 \%$ higher compared to that of inbred rice production. It revealed that per hectare total return received was Tk.104,013 from inbred rice production while it was Tk.122,433/ha from hybrid rice. However, it was clear from the analysis that total return was $18 \%$ higher for hybrid rice compared to that of inbred rice. Per hectare gross margin of hybrid rice was estimated at Tk. 72,842 while it was Tk. $56,568 /$ ha of inbred rice. So, the results seemed impressive that the gross margin of Hybrid rice was found $29 \%$ higher compared to that of inbred rice. Per hectare net returns of hybrid rice were Tk. 59,056 while it was Tk. 42,818 per hectare for inbred rice. Average net return of inbred rice was $38 \%$ lower compared to that of hybrid rice. 
Table 2. Per hectare costs of inbred and hybrid boro production.

\begin{tabular}{l|c|c}
\hline \multirow{2}{*}{ Items of cost } & Inbred HYVs & Hybrid \\
\cline { 2 - 3 } & Cost (Tk./ha) & Cost (Tk./ha) \\
\hline Human labour & $23,310(38.09)$ & $24,375(38.46)$ \\
Power tiller & $4,630(7.56)$ & $4,970(7.8)$ \\
Seed & $1525(2.49)$ & $3163(4.99)$ \\
Fertilizer & $7400(12)$ & $5905(9.31)$ \\
Insecticides & $895(1.46)$ & $1375(2.17)$ \\
Herbicides & $185(0.30)$ & $303(0.5)$ \\
Irrigation & $9,500(15.5)$ & $9,500(14.9)$ \\
Total variable cost & $47,445(77.51)$ & $49,591(78.24)$ \\
Land used cost & $12959(21.17)$ & $12959(20.44)$ \\
IOC* @ 10\% for 4 & $791(1.29)$ & $827(1.30)$ \\
month & 61,195 & 63,377 \\
Total cost & 104,013 & 122,433 \\
Gross return & 56,568 & 72,842 \\
Gross margin & 42,818 & 59,056 \\
Net return & 1.70 & 1.93 \\
BCR & &
\end{tabular}

*Note: IOC indicates interest on operating capital and figures in the parentheses indicate percentage of total cost.

It showed that benefit cost ratio of inbred and hybrid production was emerged as 1.93 and 1.70 respectively implying that Tk. 1.70 and Tk. 1.93, would be earned by spending every Tk. 1.00 investing in inbred and hybrid boro rice production. It revealed that benefit cost ratio (1.93) of hybrid rice production was higher compared to that of inbred indicating that investment in hybrid rice production would be more profitable (Table 2).

\section{Productivity and producers' efficiency}

\subsection{Estimates of stochastic frontier production function for inbred and hybrid rice production}

The maximum likelihood estimates of the parameters of the Cobb-Douglas stochastic production frontier for inbred and hybrid rice are presented in Table 2. The empirical analysis revealed that the coefficients of the variables in the 
frontier function are the elasticity of average output with respect to the different inputs used in the rice production as specified in the earlier equation (Equation no. 8). The empirical results showed that, the sign and magnitudes of the estimated $\beta$ coefficient in majority cases were consistent with prior expectation although some of them were statistically insignificant.

The estimated coefficient of seed was negative and insignificant of inbred rice while the sign of estimated coefficient of hybrid seed was positive and insignificant. The positive sign of coefficient for the fertilizer which was anticipated at $1 \%$ level of significant implying that if the amount of chemical fertilizer increased by $1 \%$, the yield of inbred would be increased by $0.350 \%$, while if fertilizer application increased by $1 \%$, the yield of hybrid rice would be increased by $0.287 \%$. Likewise, the co-efficient of insecticides for inbred rice was positive and significant at $10 \%$ level indicating that if pesticides application increased by $1 \%$, the yield of inbred rice would be increased by $0.134 \%$. The coefficient of insecticides for hybrid (i.e. 0.26) was positive and insignificant. The elasticity of human labour for inbred was negative and insignificant. On the contrary, the sign of estimated co-efficient of labour for hybrid was positive and statistically significant at $1 \%$, which indicates that if human labour increased by $1 \%$, the yield of hybrid rice would be increased by $0.101 \%$. The sign of estimated co-efficient of irrigation for inbred rice was also positive and significant at $1 \%$ level indicating that if irrigation was increased by $1 \%$, the yield would be increased by $0.103 \%$. While the estimated co-efficient of irrigation for hybrid was 0.253 and significant at $10 \%$ level indicating that if irrigation was increased by $1 \%$, the yield of hybrid rice would be increased by 0.253 .

Table 3. Maximum likelihood estimates of stochastic Cobb-Douglas production frontier for inbred and hybrid rice production.

\begin{tabular}{l|l|l|l|l|l}
\hline \multirow{2}{*}{ Name of variables } & \multirow{2}{*}{ Parameters } & \multicolumn{2}{c|}{ Inbred } & \multicolumn{2}{c}{ Hybrid } \\
\cline { 3 - 6 } & & Coefficient & t-ratio & Coefficient & t-ratio \\
\hline Constant & $\beta_{0}$ & 0.131 & $10.24^{* *}$ & 0.697 & $4.80^{*}$ \\
Ln seed & $\beta_{1}$ & -0.483 & -0.964 & 0.150 & 1.05 \\
Ln fertlizer & $\beta_{2}$ & 0.350 & $5.73^{* * *}$ & 0.287 & $3.59^{*}$ \\
Ln human labour & $\beta_{3}$ & -0.125 & -1.167 & 0.101 & $5.04^{*}$ \\
Ln Irrigation & $\beta_{4}$ & 0.103 & $7.57^{* * *}$ & 0.253 & $1.86^{* * *}$ \\
Ln insecticides & $\beta_{5}$ & 0.134 & $1.803^{*}$ & 0.260 & 1.63 \\
\hline
\end{tabular}

$* * *, *=$ Significant at $1 \%$ and $10 \%$ level, respectively. 


\subsection{Inefficiency effect on HYV and hybrid rice production}

Among the inefficiency factors in inbred rice cultivation, the estimated results showed that farm size have insignificant negative effect on the level of technical efficiency. Likewise, farm size on hybrid rice production has insignificant and negative effect on the level of technical efficiency.

Education, farming experience and contact with technology disseminators were significant for inbred rice growers at $10 \%, 1 \%$ and $5 \%$ level respectively, and their sign were negative and statistically significant indicating that if the farmers increase contact with technology disseminators, the inefficiency will be decreased (Table 3). On the other hand, efficiency will be increased. If the farmers had higher education, their inefficiency would also decrease meaning that their efficiency will be increased. The coefficient of rice farming experience was estimated to be negative and was significant at $1 \%$ level implying that experienced farmers were technically sounder than others. In other words, the levels of the inefficiency effects of farmers tend to decrease with increase in farming experience of inbred farmers.

Table 4. Maximum likelihood estimates of inefficiency function for inbred and hybrid rice production.

\begin{tabular}{|c|c|c|c|c|c|}
\hline \multirow{2}{*}{ Name of variable } & \multirow{2}{*}{ Parameters } & \multicolumn{2}{|c|}{ Inbred } & \multicolumn{2}{|c|}{ Hybrid } \\
\hline & & Coefficient & t-ratio & Coefficient & t-ratio \\
\hline Constant & $\delta_{0}$ & -0.88 & -0.154 & 0.109 & 0.957 \\
\hline Farm size & $\delta_{1}$ & -0.509 & -1.45 & -0.791 & -0.651 \\
\hline $\begin{array}{l}\text { Education (Year of } \\
\text { Schooling) }\end{array}$ & $\delta_{2}$ & -0.97 & $-1.99 *$ & -0.156 & $-5.99 *$ \\
\hline Age & $\delta_{3}$ & 0.67 & $2.729 * *$ & -0.269 & -1.49 \\
\hline $\begin{array}{l}\text { Farming Experience } \\
\text { (Years) }\end{array}$ & $\delta_{4}$ & -0.183 & $-9.52 * * *$ & 0.296 & 1.56 \\
\hline Land type & $\delta_{5}$ & 0.340 & 0.344 & -0.480 & $-10.37 *$ \\
\hline $\begin{array}{l}\text { Contact with technology } \\
\text { disseminators }\end{array}$ & $\delta_{6}$ & -0.128 & $-2.004 * *$ & 0.318 & 0.992 \\
\hline Seedling age & $\delta_{7}$ & -0139 & $-2.44 * *$ & -0.395 & $-8.88^{*}$ \\
\hline Seedlings (no/hill) & $\delta_{8}$ & -0.391 & $-1.91^{*}$ & -0.1037 & $-6.77 *$ \\
\hline Log-likelihood value & & 9.05 & & 17.80 & \\
\hline Mean technical efficiency & & 0.79 & & 0.86 & \\
\hline \multicolumn{6}{|l|}{ Variance Parameter: } \\
\hline Sigma squared & $\Sigma^{2}$ & 0.315 & $2.84 * *$ & 0.07 & $4.24 *$ \\
\hline Gamma & $\gamma$ & 0.99 & $26.014 * * *$ & 0.197 & $10.97 *$ \\
\hline
\end{tabular}

$* * *, * * *=$ Significant at $1 \%, 5 \%$ and $10 \%$ level, respectively. 
The coefficient of farmers' age was estimated to be positive and was significant at 5\% level. On other hand, the coefficient of education for hybrid rice farmers was significant at $10 \%$ and the sign was negative indicating that if the farmers had higher education, their inefficiency will decrease in hybrid rice production meaning that their efficiency will increase.

The coefficient of land type was estimated to be positive and insignificant which indicates that land type had no effects on technical efficiency of inbred rice production while the co-efficient for land type dummy was negative and significant at $1 \%$ implying that those farmers growing hybrid rice in the low land, their inefficiency decrease, in other words, technical efficiency increases. This is because farms with high land suffer from water disturbance and ultimately lower yields leading to increase inefficiency.

The coefficient for seedling number for inbred rice growers were negative and significant at $10 \%$ implying that farmer who used lower number of seedlings per hill and their inefficiency decreases significantly or in other words; their technical efficiency increases since they used lesser seedlings per hill. On the other hand, the coefficient for seedling number for hybrid rice growers was negative and highly significant at $1 \%$ implying that those farmers used one seedling per hill their inefficiency would decreases significantly or in other words their technical efficiency increases since they used one seedling per hill. The reason could be that, higher number of seed/seedling per hill helps develop higher number of tiller in the plot resulting in less plant growth and vigor, this eventually causes lesser yield performance and therefore, the level of efficiency of the producers decrease.

The coefficient for seedling age for inbred rice was found to be negative and significant at 5\% indicating that the farms used seedlings of lesser age, their inefficiency decreases significantly. In other words, their technical efficiency increases that helped them in getting higher yield. It was observed that those farmers transplanted the seedling of 30-40 days they obtained higher yield than those used more aged seedling. While the coefficient for seedling age was found to be negative and highly significant showing that those sample farms used seedlings of lesser age, their inefficiency decreases significantly. In addition, their technical efficiency increases.

\section{Level of technical efficiency of inbred HYV and hybrid farmers}

The empirical results revealed that the estimated technical efficiency of hybrid rice farmers was higher than that of inbred rice farmers. In cultivating inbred rice, average technical efficiency was about $79 \%$ and nearly $23 \%$ farms attained efficiency belongs and close to the average efficiency of category of 76-80. This implies that, on average, about $94 \%$ farmers were on the potential frontier 
production level, given the levels of their inputs and the technology currently being used and there is about $20 \%$ technical inefficiencies in producing inbred rice. On the other hand, in producing hybrid varieties average efficiency was about $86 \%$ and $51 \%$ farms attained efficiency level belongs and close to the efficiency category of $86-90$. This also implies that, about $86 \%$ hybrid rice farmers were on the potential frontier production levels, given the levels of their inputs and the technology currently being used and there is also $14 \%$ technical inefficiencies in producing hybrid rice. The range of efficiency of the HYV rice farms exists between $13 \%$ to $97 \%$ while that range of the hybrid rice farms hybrid exists between $62.3 \%$ to $98.6 \%$. The estimated results also showed that there is a greater scope of increasing yield, breaking the frontier for hybrid and inbred rice. About 20 and 14\% yield for inbred HYV and hybrid rice could be increased even with the existing varieties respectively, if the management practices of the identified parameters are improved (Table 5).

Table 5. Level of technical efficiency for inbred and hybrid rice producers.

\begin{tabular}{ccc}
\hline \multicolumn{1}{c|}{ Particulars } & Inbred & Hybrid \\
\hline $\begin{array}{c}\text { Number of farms } \\
\text { \% farm under categories }\end{array}$ & 40 & 40 \\
$>55$ & 10 & 0 \\
$55-60$ & 8 & 0 \\
$61-65$ & 8 & 3 \\
$66-70$ & 3 & 5 \\
$71-75$ & 10 & 10 \\
$76-80$ & 5 & 8 \\
$81-85$ & 8 & 18 \\
$86-90$ & 10 & 20 \\
$91-95$ & 28 & 13 \\
$<96$ & 13 & 25 \\
Mean efficiency & 0.79 & 0.86 \\
Standard deviation & 0.1817 & 0.09323 \\
Minimum efficiency & 0.129 & 0.623 \\
Maximum efficiency & 0.973 & 0.986 \\
\hline
\end{tabular}

Source: Author's estimation. 


\section{Constraints to rice production}

Almost all farmers reported that non-availability of inputs like fertilizer, insecticides, etc. at fair price was a problem in the line with increasing paddy. The small farmers were out of purchasing capacity and they could not buy insecticides for their crops. All sample farmers mentioned that electric load shedding was a critical problem for boro production because it reduces yield of paddy drastically due to disturbance of irrigation. Almost all farmers opined that low price of boro paddy, particularly just after harvesting of the products caused disincentive to the farmers for growing boro rice. They had to sell a large portion of total production to repay debts or outstanding for inputs. But finding no other alternatives, farmers had to sell their produces at a lower price. Although some farmers had basic knowledge of input use and crop management of modern HYVs production, but $98 \%$ hybrid rice farmer had no scientific knowledge in farming hybrid rice. Nearly $76 \%$ hybrid rice farmers reported that biotic stress like stemborer, rice hispa, rice bug, brown plant hopper, greenleaf hopper, galmidge, rice caterpiller and mites hindrance to the hybrid production. But relatively most common among these biotic stresses was the stem borer. More than $70 \%$ farmers of both type of varieties said that boro is a labour intensive crop. Scarcity of human labour leading to higher wage is one of the major problems for cultivating boro rice especially during the time of transplanting and harvesting period. About $43 \%$ inbred rice farmers reported that at present lack of quality seeds and its high price is one of the limiting factors of boro paddy production. In case of hybrid seed, all sample farmers had to buy from market. However, about $31 \%$ farmers are very worrying about quality of hybrid seed. Therefore the farmers cultivated hybrid rice from their basic concepts. About $25 \%$ expressed that the quality of hybrid rice is not up to mark and the stickiness of cooked rice was more serious. Cooked hybrid rice cannot be kept for long time.

\section{Conclusions and policy recommendations}

Results revealed that cost of hybrid rice production was about $4 \%$ higher compared to that of inbred rice production. The analysis further revealed that total return was $18 \%$ higher for hybrid rice compared to inbred rice. So, the results seemed impressive that the gross margin of hybrid rice was found $29 \%$ higher compared to that of inbred rice. Average net return of inbred rice was $38 \%$ lower compared to that of hybrid rice. Undiscounted benefit cost ratio of inbred and hybrid production was emerged as 1.93 and 1.70 respectively further indicating that return from investment of hybrid rice cultivation was higher. 
Table 6. Problems faced by the sample farmers in growing hybrid rice.

\begin{tabular}{l|c|c}
\hline \multirow{2}{*}{\multicolumn{1}{c}{ Problems }} & \multicolumn{2}{c}{$\%$ of sample farmers } \\
\cline { 2 - 3 } & Inbred & Hybrid \\
\hline High prices of fertilizer and insecticides & 100 & 100 \\
Lack of electricity & 100 & 100 \\
Low price of paddy & 100 & 100 \\
Lack of scientific knowledge about rice & - & 98 \\
production & - & 76 \\
Biotic constraint to hybrid rice production & 76 & 74 \\
Lack of human labour & 41 & 31 \\
Lack of quality rice seeds & 35 & 43 \\
Lack of extension service & - & 26 \\
Problem of consumption of hybrid rice & & \\
\hline
\end{tabular}

Source: Survey, 2008

It was observed that the coefficient of seed and human labour for inbred was negative and insignificant. The coefficient of the fertilizer, irrigation and insecticides of inbred are positive and significant at $1 \%$, and $10 \%$ level respectively. On the other hand, the coefficient of human labour, fertilizer and irrigation and insecticides of hybrid are positive and significant at $10 \%$, and $1 \%$ level respectively. It was further observed that the mean technical efficiency was about $80 \%$ for inbred and $86 \%$ for hybrid rice producer, respectively, which indicated that the hybrid rice farmers were technically more efficient than inbred producers. Higher-level of education and more contact with technology disseminators were found to contribute in reducing technical inefficiency of both inbred and hybrid boro producers. Almost all farmers reported that although, both inbred and hybrid cultivation faced some problems but it was more severe for hybrid rice cultivation. High quality locally produced hybrid rice varieties should be developed which is suitable for Bangladesh and side by side domestic seed production should be expedited. In developing hybrid, due priority should be given to those hybrids which are suitable for rain-fed and are resistant to biotic stresses. Input price should be kept within the affordability and price of output should be ensured for the produces of the farmers. Market monitoring committee should be set up in order to control the adulteration of chemical fertilizer and pesticides and also control input prices

\section{References}

Ahmed, R. 2001. Restropects and Prospects of the Rice Economy of Bangladesh, The University Press Limited, Red Cresent Buidling, Dhaka. 
Aigner, D., C.A.K. Lovell and P. Schmidt. 1977. Formulation and Estimation and Stochastic Frontier Production function Models. Journal of Econometrics 6: 21-37.

Battese, G.E. and T.J. Coelli. 1993. A Stochastic Frontier Production Function Incorporating a Model for Technical Inefficiencies Effect", Working Paper in Economics and Applied Statistics, No. 69.

BBS. 2009. Statistical Year Book of Bangladesh", Bangladesh Bureau of Statistics, Ministry of Planning, Government of the People's Republic of Bangladesh, Dhaka.

BBS. 2010. Bangladesh Population Census, Bangladesh. Bureau of Statistics, Statistical Division, Ministry of Planning government of the People's of Bangladesh, Dhaka.

BER. 2010, Bangladesh Economic Review, Department of Finance, Ministry of Finance, Govt. of the People's Republic of Bangladesh, Dhaka, The People's Republic of Bangladesh, Dhaka.

Bravo-Utera, B. E. and R. E. Evenson. 1994. Efficiency in agricultural production: The case of peasant farmers in Eastern Paraguaguay. Agricultural Economics 10(2): 27-37.

Bravo-Ureta, B.E. and L. Rieger. 1991. Farm efficiency measurement using stochastic frontiers and neoclassical duality. American Journal of Agricultural Economics 73: 421-428.

Bravo-Ureta, B.E. and R. E. Evenson. 1994. Efficiency in agricultural production: The case of peasant farmers in Eastern Paraguay. Agricultural Economics 10: 27-37.

Coelli, T.J. 1995. Estimators and Hypothesis Tests for a Stochastic Frontier Function: A Monte Carlo Study. Journal of Productivity Analysis 6: 247-268.

Coelli, T.J. 1996. A Guide to Frontier Verson 4.1: A Computer Program for Stochastic Frontier Production and Cost Function Estimation. CEPA working paper 7/96, Centre for Efficiency and Productivity Analysis, University of New England, Armidale.

Kopp, R. J. and V. K. Smith. 1982. Frontier production function estimates for steam electric generation: A comparative analysis. Southern Economic Journal 47(10): 49-59.

DAE. 2010. Directorate of Agriculture Extension, Ministry of Agriculture, Bangladesh

Meeusen, W., and J. VandenBroeck, 1977. Efficiency estimation from Cobb-Douglas production functions with composed error. International Economic Review 18: 435-444.

Rome.Xiaosong, $\mathrm{Xu}$ and S. R. Jeffrey. 1998. Efficiency and Technical Progress in traditional and Modern Agriculture: Evidence from Rice Production in China. Agricultural Economics 18(2): 157-165. 